\title{
DaNos Ricochetes OU REFLEXOS DOS PARENTES E PESSOAS PRÓXIMAS DAS VÍTIMAS DA DITADURA MILITAR NO BRASIL
}

Ricochetes damages or consequences of relatives and people next victims of military dictatorship in Brazil

Murilo Naves Amaral Mestrando em Direito Público pela Universidade Federal de Uberlândia (UFU). E-mail: murilonamaral@gmail.com

\section{Hárrisson Fernandes dos Santos} Mestrando em Direito Público pela Universidade Federal de Uberlândia (UFU). E-mail: harrissonferanndes@yahoo.com.br

RECEBIDO EM: 30.08 .12

APROVADO EM: 01.12.12

\section{RESUMo}

A construção da realidade democrática nacional nem sempre se deu dentro de um contexto em que os direitos e garantias fundamentais fossem observados e respeitados pelas autoridades instituídas. Nesse sentido, o Brasil, entre os anos de 1964 a 1985, viveu um período de "Estado de não Direito" em que acusou-se a supressão dos direitos e garantias individuais. Assim, mesmo após o transcorrer do tempo, observa-se ainda a ocorrência de danos em face de indivíduos que, embora não tenham sido vítimas diretas do regime, o foram pelo fato de serem familiares ou pessoas próximas daqueles perseguidos pelos agentes estatais. Verifica-se, portanto que, existe a possibilidade de reparação civil em função dos danos ricochetes ou reflexos sofridos por essas pessoas.

Palavras-chave: Ditadura. Estado. Dano. Ricochete. Reparação. 


\begin{abstract}
The construction of the national democratic reality has not always within a context in which the fundamental rights and guarantees were observed and respected authorities instituted. In this sense, Brazil, between the years 1964 to 1985 , experienced a period of "no rule of law" in which he accused the suppression of individual rights and guarantees. Thus, even after the passage of time, there is still damage from occurring in the face of individuals who, although they were not direct victims of the regime, because they were relatives or people close to those persecuted by state agents. It is apparent, therefore, that there is the possibility of repairing the damage calendar function bumpers or reflections suffered by these people.
\end{abstract}

Keywords: Dictatorship. State. Damage. Rebound. RePair.

SuMÁRIO: Introdução. 1. A justiça de transição no Brasil e a revisão da lei 6.683/79. 2. A responsabilidade estatal e as legislações criadas com a finalidade de resgatar a verdade e a memória. 3. A responsabilidade civil do Estado em razão de danos reflexos ou ricochetes sofridos por parentes e pessoas próximas às vítimas do regime militar. 4. A inexistência de prescrição da reparação civil por danos ricochetes ou reflexos dos parentes e pessoas próximas das vítimas da ditadura militar. Conclusão. Referências.

\title{
INTRODUÇÃO
}

A história brasileira recente conviveu entre os anos de 1964 a 1985 , com um regime extremamente autoritário e opressor. Conforme se pode extrair por relatos e documentos históricos, observa-se que esses mais de vinte anos representaram um período reconhecido pela supressão de direitos e garantias fundamentais e arbitrariedades impostas pelo próprio Estado.

Nesse sentido, tendo em vista que a finalidade proposta pelo regime foi a de justificar a partir de premissas autoritárias e contraditórias, a manutenção da própria democracia, o que se verificou, na verdade, foi à configuração de uma realidade destoante das premissas exigidas para a constituição de um Estado Democrático de Direito.

É sabido que o Direito, na acepção burguesa, surge como uma realidade conformadora, que visa o estabelecimento da paz e ordem social. Ademais, 
reportando a concepção contratualista, também o surge para resguardar ao indivíduo suas liberdades individuais ao mesmo tempo em que estabelece a proteção de direitos e garantias voltados à sociedade. Ocorre que a realidade conformadora do Direito, na ditadura militar instaurada no Brasil, cambiou-se naquela em que cidadãos foram perseguidos e que o aparato estatal, conforme mencionado em linhas anteriores, tomou para si o controle da sociedade de modo a condicionar o indivíduo e não mais garantir as liberdades fundamentais precípuas em uma realidade de normalidade institucional.

Consequentemente, verificar-se-á no trabalho a que se propõe que, com o adiantar dos anos, a sociedade brasileira maculada e ainda com sequelas da ditadura militar começa a evoluir no campo legislativo no sentido de buscar a reparação daqueles que foram vítimas do regime.

Enfim, observa-se que, além desses pontos, não apenas os indivíduos isoladamente considerados foram vítimas dos agentes estatais durante a ditadura militar. Indo mais além, verifica-se que os familiares e pessoas próximas também sofreram sequelas e danos decorrentes das perseguições e opressões estatais. Verifica-se a existência de indivíduos vítimas de danos do período militar em função de serem parentes ou pessoas próximas de perseguidos políticos.

Ressalta-se, por fim, que com a transição democrática há um processo de construção de um sistema jurídico capaz de suscitar as questões acima demonstradas, como essenciais para a consolidação da democracia brasileira, de modo que haja possibilidade das vítimas do regime militar serem devidamente reparadas. Portanto, pelas razões que buscará demonstrar nos capítulos que sucedem, verificará a fundamentação da possibilidade de reparação civil por danos reflexos derivados do período ditatorial.

\section{A JustiÇa de transição no Brasil e a ReVisão da lei 6.683/79}

Durante um período de cerca de vinte anos, que perdurou entre 1.964 a 1.985, a sociedade brasileira passou por uma das fases mais sombrias de sua história, em que se instalou um regime extremamente autoritário, com perseguições contra aqueles que se opunham ao governo, por meio de prisões arbitrárias, desaparecimento de pessoas, torturas e homicídios que foram praticados por agentes de Estado.

No período da ditadura militar houve a implementação daquilo que poderia se denominar como "Estado de não direito" em que "não se reconhece aos indivíduos uma esfera de liberdade ante o poder protegida pelo direito" (CANOTILHO,1999, p.11).

Todavia, passado quase trinta anos do fim do regime militar, os que praticaram crimes em favor do Estado, que atualmente poderiam ser 
considerados hediondos, não foram punidos, por ter sido determinado aquilo que ficou conhecido como "anistia-recíproca" (HERKENHOFF, 2004, p.120), em decorrência da lei 6.683/79, que foi incorporada pela EC 26/1985, na qual tanto aqueles que se opuseram ao regime como aqueles que atuaram em nome do Estado por meio de condutas repressivas estariam anistiados.

A lei $6.683 / 79$ foi duramente criticada ${ }^{93}$, uma vez que considerou que os atos praticados pelos agentes de repressão se tratavam de crimes políticos ou conexos com estes, o que dessa forma, levantou inúmeras discussões sobre como a mencionada disposição legal deveria ser interpretada.

Diante do amadurecimento das discussões sobre o caso e das polêmicas geradas, em outubro de 2008 é proposta pelo Conselho Federal da Ordem dos Advogados do Brasil, a Arguição de Descumprimento de Preceito Fundamental nº153 (ADPF 153), com a finalidade de requerer a interpretação conforme a Constituição, do art. $1^{\circ}$ da Lei Federal $n^{\circ}$ $6.683 / 79$, de modo a não estender a aplicação do mencionado dispositivo legal aos agentes de repressão, visto que estes, durante a ditadura militar, cometeram crimes comuns, sem qualquer conexão a crimes políticos.

Todavia, o Supremo Tribunal Federal, em uma decisão política ${ }^{94}$, por 7 votos a 2 indeferiu a ADPF 153 e declarou válida, em sua integralidade, a lei $6.683 / 79$, uma vez que dentre os fundamentos mais utilizados pelos Ministros, foi que a mencionada legislação seria fruto de uma realidade histórica que em razão de um acordo de vontades preferiu a reconstrução da democracia a

\footnotetext{
${ }^{93}$ Conforme preceitua Lauro Joppert Swensson Júnior (In: DIMOULIS. MARTINS. SWENSSON JÚNIOR, 2010, pp. 26-27) "condutas tipificadas como delitos graves foram praticados de maneira sistemática por agentes estatais durante a repressão política da ditadura. As torturas, os desaparecimentos forçados e as execuções sumárias marcaram a história do país. Uma história que insiste em não passar. E ninguém foi penalmente responsabilizado pelas suas ações criminosas. $\mathrm{O}$ principal fundamento jurídico empregado ao longo dos anos para assegurar a impunidade dessas pessoas é a Lei 6.683, de 28 de agosto de 1979 que, segundo interpretação que prevaleceu na prática, concedeu anistia não só aos presos e exilados por crimes políticos, mas também aos agentes estatais e colaboradores da ditadura, responsáveis pelos delitos relacionados à repressão política. Apesar disso, persiste em nosso país as discussões se os "culpados" pela criminalidade do regime militar ou não devem ser punidos, e como é possível realizar essa punição."

${ }^{94}$ Em artigo publicado na revista Carta Capital, o desembargador aposentado do Tribunal de Justiça de São Paulo, Wálter Maierovitch, expôs que o "o STF, diversas vezes, optou por decisões políticas. Por exemplo, ao decidir pela legitimidade da denominada lei da anistia, aprovada por Parlamento biônico e cunhada pelos militares para garantir a impunidade em face de consumados crimes de lesa-humanidade, os ministros, por maioria e conduzidos pelo voto de Eros Grau, deram uma decisão política, além de canhestra."(MAIEROVITCH, Wálter. Supremos Momentos. Disponível em http://www.cartacapital.com.br/politica/supremos-momentos/?autor=18. Acessado em 13.07.2012.)
} 
partir daquilo que o relator da demanda, Ministro Eros Graus, denominou de "transição conciliada"5",

Ressalta-se que o Supremo Tribunal Federal ao adotar tal postura, se contrapõe aos fundamentos do Estado Democrático, as dimensões políticas da Justiça de Transição e aos Tratados Internacionais de Direitos Humanos aos quais o Brasil faz parte ${ }^{96}$, na medida em que legitima práticas criminosas praticadas por agentes estatais durante o período da ditadura militar.

Compreender os tratados internacionais de direitos humanos como "mera convencionalidade" traz à tona a crise existente no Estado moderno e, por conseguinte, o Estado brasileiro, posto que desconsidera o direito internacional como forma de proteger a dignidade da pessoa humana. Neste diapasão demonstra Luigi Ferrajoli (2002, p.46):

Repensar o Estado em suas relações externas à luz do atual direito internacional não é diferente de pensar o Estado em sua dimensão interna à luz do direito constitucional. Isso quer dizer analisar as condutas dos Estados em suas relações entre si e com seus cidadãos - as guerras, os massacres, as torturas, as opressões das liberdades, as ameaças ao meio ambiente, as condições de miséria e fome nas quais vivem enormes multidões de seres humanos -, interpretando-as não como males naturais, tampouco como simples "injustiças", quando comparadas com uma obrigação utópica de ser moral ou política, mas sim como violações jurídicas reconhecíveis em relação à obrigação de ser do direito internacional vigente, tal como ele já está vergado em seus princípios fundamentais.

Notadamente a política transicional adotada no Brasil, diferentemente do que ocorreu em países como Chile e Argentina, trata-se de caso bastante

\footnotetext{
${ }^{95}$ Cf. voto Min. Eros Grau na ADPF 153.

${ }^{96}$ A Corte Interamericana de Direitos Humanos, ao analisar o julgamento da ADPF 153, desenvolve a idéia do que denomina como "controle de convencionalidade" expondo que: "Este Tribunal estabeleceu em sua jurisprudência que é consciente de que as autoridades internas estão sujeitas ao império da lei e, por esse motivo, estão obrigadas a aplicar as disposições vigentes no ordenamento jurídico. No entanto, quando um Estado é Parte de um tratado internacional, como a Convenção Americana, todos os seus órgãos, inclusive seus juízes, também estão submetidos àquele, o que os obriga a zelar para que os efeitos das disposições da Convenção não se vejam enfraquecidos pela aplicação de normas contrárias a seu objeto e finalidade, e que desde o início carecem de efeitos jurídicos. O Poder Judiciário, nesse sentido, está internacionalmente obrigado a exercer um "controle de convencionalidade" ex-officio entre as normas internas e a Convenção Americana, evidentemente no marco de suas respectivas competências e das regulamentações processuais correspondentes. Nessa tarefa, o Poder Judiciário deve levar em conta não somente o tratado, mas também a interpretação que a ele conferiu a Corte Interamericana, intérprete última da Convenção Americana." (CORTE IDH. Caso Gomes Lund e outros (Guerrilha do Araguaia) apud KRSTICEVIC. AFFONSO. In GOMES; MAZZUOLLI, 2011, p.272).
} 
peculiar, visto que ao mesmo tempo que reconhece o direito de resgate a memória e a verdade, conforme foi proferida na própria decisão do Supremo Tribunal Federal no julgamento da ADPF $153^{97}$, não instituiu medidas com a finalidade de punir os agentes estatais que agiram em contraposição às garantias e direitos fundamentais.

Destaca-se que no período ditatorial, não foi exclusividade do Brasil apoiarse no aparato militar para assumir o controle do país, posto que outros países latino-americanos também contaram com a mesma rebelião das forças militares na tomada do poder. Em decorrência da chamada "Guerra Fria", em que o mundo bipolar, na qual duas nações buscavam o poderio político e econômico, a incursão dos golpes foi de certo modo facilitada e respaldada internacionalmente.

Nesse contexto, com a derrocada desses regimes autoritários, observa-se que cada nação redemocratizada deu sentido próprio ao modo de promover a sua Justiça de Transição de forma a adequar no seu contexto histórico, como ocorreu no Chile que criou a sua Comissão da Verdade ${ }^{98}$, em momento anterior ao Brasil e no caso argentino ${ }^{99}$.

\footnotetext{
${ }^{97}$ Como pode se verificar em trecho do voto do Ministro Eros Grau no julgamento da ADPF 153, de forma simultânea, houve o reconhecimento ao direito a verdade e a memória, porém a possibilidade de punibilidade dos agentes do regime opressor foi denegada, posto que de acordo com o próprio ministro "o estado democrático de direito, para além da discussão acerca da punibilidade, precisa posicionar-se sobre a afirmação e concretização do direito fundamental à verdade histórica."(vide ADPF 153)

${ }^{98}$ No Chile, em 1978, foi promulgado um decreto de anistia que perdoava os crimes dos agentes do próprio Estado. Logo após tomar posse, o presidente Patricio Aylwin (1990-1994) anunciou a criação da Comissão Nacional de Verdade e Reconciliação, cujo objetivo principal era "contribuir para o esclarecimento global da verdade sobre as mais graves violações de direitos" no país ou no exterior, desde que relacionadas com o Estado chileno ou com a vida política nacional. A comissão chilena despachou cerca de mil ofícios com pedidos de esclarecimentos. Disponível em $<$ http://ultimosegundo.ig.com.br/mundo/2012-05-16/comissao-da-verdade-chega-com-atraso-ao-brasil-em-relacao-a-outr.html. Acessado em 26.07.2012.

${ }^{99} \mathrm{Na}$ Argentina, logo após assumir a presidência, Raúl Alfonsín (1983-1989) criou a Comissão Nacional sobre o Desaparecimento de Pessoas (Conadep), destinada a investigar os desaparecimentos forçados e produzir um relatório. Foram inspecionadas instalações policiais e militares e visitados cemitérios públicos e clandestinos, onde havia corpos não-identificados. Em setembro de 1984, nove meses depois de ouvir mais de 7 mil depoimentos e entrevistar mais de 15, mil sobreviventes, a Conadep concluiu e entregou seu relatório, com cerca de 50 mil páginas, ao presidente Alfonsín, representando um "paradigma mundial" por seu pioneirismo.

A Argentina foi também o primeiro país da região a levar peças-chave do regime militar ao banco dos réus. O ex-presidente Jorge Rafael Videla (1976-1981) e outros foram condenados durante o governo de Alfonsín, que mais tarde assinou uma espécie de perdão aos militares de menor escalão. Anos depois o ex-presidente Carlos Menem (1989-1999) indultou tanto ex-líderes militares e ex-guerrilheiros. A partir de 2003, no entanto, o governo do ex-presidente Néstor Kirchner (2003-2007) reabriu investigações sobre os crimes da ditadura, depois de a Suprema Corte
} 
Naturalmente, pondera-se que o contexto histórico vivenciado pela Argentina era outro, principalmente considerando o fato do governo militar ter inserido o país na sangrenta "Guerra das Malvinas". Acredita-se que a rejeição e baixa popularidade estatal permitiram o estabelecimento de uma investigação mais aprofundada do período repressor.

No Brasil, embora se deva reconhecer que o processo de transição instituiu "indiscutível avanço na consolidação legislativa das garantias e direitos fundamentais e na proteção de setores vulneráveis da sociedade brasileira" (PIOVESAN, 2007, p. 27) é irrefutável também que o Supremo Tribunal Federal, ao decidir pela não punição dos agentes estatais durante a ditadura militar, provoca um retrocesso no processo de redemocratização.

Observa-se também que o Supremo Tribunal Federal, em sua decisão reflete a construção da sociedade brasileira a partir de um viés autoritário, na qual as instituições são construídas sem que haja interesse ao atendimento das demandas sociais, ao mesmo tempo em que servem de estrutura para manutenção de uma herança patrimonialista e de privilégios a uma classe dominante, ainda que para isso haja violações de direitos humanos, como ocorreu no regime militar ${ }^{100}$.

\section{A Responsabilidade estatal E AS LEgislações CRiAdas COM A FINALIDADE DE RESGATAR A VERDADE E A MEMÓRIA}

A ausência de punição na esfera penal dos agentes estatais que praticaram crimes comuns durante o regime militar, não impede a responsabilização civil do Estado, tanto em relação àqueles que tiveram sua dignidade infringida, por terem sofrido torturas, violência sexual entre outras práticas, como também em relação aos parentes das milhares de vítimas, que tiveram de lidar com as consequências de ter uma pessoa próxima constrangida por um regime autoritário, visto que houve sérias violações a direitos de personalidade, devidamente consagrados pela legislação pátria atual.

de Justiça declarar as leis nulas. Os militares beneficiados com aquelas leis foram condenados e presos, e outros processos continuam até hoje. Disponível em http://ultimosegundo.ig.com.br/ mundo/2012-05-16/comissao-da-verdade-chega-com-atraso-ao-brasil-em-relacao-a-outr.html. Acesso em 2.07.2012.

${ }^{100}$ Conforme demonstra Wolkmer (2003, p.148) “é preciso ter presente que não só a organização da sociedade brasileira se constitui sobre a escravidão e sobre o latifúndio, como também, toda nossa evolução política, do descobrimento à república, foi marcada pela herança de uma administração elitista e centralizadora. Sob certo aspecto, a colonização portuguesa determinou a formação, no Brasil, de um Estado oligárquico e intervencionista. Este modelo excludente de estrutura estatal influenciou o desenvolvimento de um pensamento patrimonialista, burocrático, estamental e essencialmente autoritário". 
A ideia de responsabilidade estatal surge com o intuito de dar uma resposta ${ }^{101}$, ainda que limitada no âmbito civil, a todos àqueles que sofreram em razão das perseguições ocorridas por um Estado que de forma autoritária e ilegítima, buscou impor um sistema político com a finalidade de atender os interesses de uma classe dominante, o que não logrou êxito, uma vez que não conseguiu manter uma estabilidade econômica, capaz de dar suporte ao regime ${ }^{102}$.

Cumpre salientar que a responsabilização do Estado no presente caso, como provém de ato comissivo, deverá ser objetiva ${ }^{103}$, haja vista que, conforme expõe Celso Antônio Bandeira de Melo (2002, p.852) "a própria noção de Estado de Direito postula esta solução".

Insta demonstrar que embora, em muitos casos, estivessem agindo sob o manto da legalidade ${ }^{104}$, as práticas cometidas durante o regime militar contra aqueles que se opunham ao governo golpista, estavam eivadas de ilegitimidade, o que por si só, provoca a possibilidade de reparação pelos danos sofridos ${ }^{105}$.

${ }^{101}$ De acordo com Antônio Queiroz Telles (1995, p.409) a responsabilidade advém do vocábulo verbal latino respondere, que por sua vez tem o sentido de responder ou replicar.

${ }^{102}$ Ilustra Alysson Leandro Mascaro (2008, p. 164) que o "autoritarismo político do regime militar, empreendendo uma dominação social que alijava as classes proletárias e miseráveis da participação política, não logrou porém a estabilidade do regime econômico da qual era o suporte político. As contradições de um capitalismo exportador, de uma sociedade industrializada, mas sem o fomento do mercado interno, somada às constantes pressões internacionais nos compromissos de financiamento e dívida, que aumentavam em grande monta, todas estas contradições, e mais o aumento do grau de pauperização das massas trabalhadora, levam à ruptura do sistema político ditatorial e de seus postulados jurídicos autoritários."

${ }^{103}$ Nas escritas de Pablo Stolze e Rodolfo Pamplona Filho (2012, p.58-59), a responsabilidade objetiva é aquela em que "o dolo ou culpa na conduta do agente causador do dano é irrelevante juridicamente, haja vista que somente será necessária a existência do elo de causalidade entre o dano e a conduta do agente responsável para que surja o dever de indenizar."

${ }^{104}$ Em entrevista concedida a Agência Brasil, Vladimir Saflate expõe que a ditadura militar "inaugurou um regime extremamente perverso que consiste em utilizar a aparência da legalidade para encobrir o mais claro arbítrio. Tudo era feito de forma a dar a aparência de legalidade. Quando o regime queria de fato assassinar alguém, suspender a lei, embaralhava a distinção entre estar dentro e fora da lei. Fazia isso sem o menor problema. Todos viviam sob um arbítrio implacável que minava e corroía completamente a ideia de legalidade. É um dos defeitos mais perversos e nocivos que uma ditadura pode ter." (Tentando apagar a história da ditadura, por Vladimir Saflate. Carta Capital. Disponível em: http://www.cartacapital.com.br/politica/vladimir-safatle-tentando-apagar-a-historia-da-ditadura/. Acessado em 10 de julho de 2012. ).

${ }^{105}$ Segundo Celso Antônio Bandeira de Melo (2002, p.853) "em muitos casos a conduta estatal geradora do dano não haverá sido legítima, mas, pelo contrário, ilegítima. Sem embargo, não haverá razão, ainda aqui, para variar as condições de engajamento da responsabilidade estatal. Deveras, se a conduta legítima produtora do dano enseja responsabilidade objetiva, a fortiori deverá ensejá-la a conduta ilegítima causadora da lesão jurídica. É o que tanto numa como noutra hipótese o administrado não tem como se evadir à ação estatal. Fica â sua mercê, sujeito a um poder que 
Apesar de se reconhecer que o Estado, pelo menos em regra, não desempenha atividade ilícita, como muito bem ilustra Arnaldo Rizzardo (2007, p. 370) "no seu desenvolvimento surgem os desvios, a imprudência, a negligência, a imperícia, ou o dolo, isto é, a criminalidade".

Neste sentido é o entendimento de Celso Antônio Bandeira de Melo (2002, p. 863):

No caso de comportamentos comissivos, a existência ou inexistência do dever de reparar não se decide pela qualificação da conduta geradora do dano (ilícita ou lícita), mas pela qualificação da lesão sofrida. Isto é, a juridicidade do comportamento danoso não exclui a obrigação de reparar se o dano consiste em extinção ou agravamento de um direito.

A legalidade, por si só, não pode ser utilizada como meio de se escusar das responsabilidades derivadas dos danos provocados a terceiros, haja vista que, embora seja a ilicitude que geralmente culmina na ideia de responsabilização, conforme muito bem explana José dos Santos Carvalho Filho (2004, p. 443), "o ordenamento jurídico faz nascer a responsabilidade até mesmo de fatos lícitos." Aliás, indo além disso, como muito bem demonstra Roberto Lyra Filho (2006, p.10), "se o Direito é reduzido a pura legalidade, já representa dominação ilegítima."

Do mesmo modo expõe Fabio Konder Comparato (In Castro, 1999, p.16):

A força normativa dos princípios é muito maior que a das simples regras do direito, porque estas vigem na exata medida em não colidem com aqueles. A função própria dos princípios consiste, justamente, em dar unidade ao sistema jurídico, direcionando a interpretação e a aplicação de suas normas e gerando novas regras em caso de lacunas.

Em face de tal cenário, não tendo sido acolhida pelo direito brasileiro a tese da irresponsabilidade do Estado ${ }^{106}$, haja vista que, conforme ilustra Maria Sylvia Zanella Di Pietro (2006, p. 622), sempre houve um repúdio pela doutrina e pelos tribunais pátrios a referida teoria, o entendimento mais correto seria o

investe sobre uma situação juridicamente protegida e a agrava. Saber-se, pois, se o Estado agiu ou não culposamente (ou dolosamente) é questão irrelevante. Relevante é a perda da situação juridicamente protegida. Este só fato já é bastante para postular a reparação patrimonial".

${ }^{106}$ De acordo com José dos Santos Carvalho Filho (2004, p. 446) "na metade do século XIX, a ideia que prevaleceu no mundo ocidental era a de que o Estado não tinha qualquer responsabilidade pelos atos praticados por seus agentes." Continua o renomado autor a expor que "essa teoria não prevaleceu por muito tempo em vários países. A noção de que o Estado era o ente todo-poderoso, confundida com a velha teoria da intangibilidade do soberano e que o tornava insuscetível de causar danos e ser responsável, foi substituída pela do Estado de Direito, segundo o qual deveriam ser a ele atribuídos os direitos e deveres comuns às pessoas jurídicas." 
da responsabilização civil do Estado pelas práticas dos agentes de repressão durante o regime militar, ainda que o Supremo Tribunal Federal tenha decidido, de forma absolutamente inadequada, no julgamento da ADPF 153, contra a punição criminal desses servidores estatais.

Nota-se que a legislação vem criando mecanismos com a finalidade de resgatar a memória e a verdade, ao mesmo tempo em que estabelece a reparação das vitimas do regime militar. O ponto inicial de tais medidas se deu com a promulgação da lei 9.140 de 1995, que criou a Comissão Especial de mortos e desaparecidos políticos, com a finalidade de apurar os fatos ocorridos entre o período de 2 de setembro de 1961 a 5 de outubro de 1988.

Em novembro de 2002, foi promulgada a lei 10.559, com a finalidade de regulamentar o art. $8^{\circ}$ do Ato das Disposições Constitucionais Transitórias, que dentre outras providências, determinou a reparação econômica daqueles que foram vítimas do regime militar, mediante portaria do Ministro da Justiça, após parecer favorável da Comissão de Anistia ${ }^{107}$.

Ainda que a lei 10.559/02 tenha surgido para somente providenciar uma reparação econômica a todos aqueles que foram vítimas da ditadura militar, a mencionada legislação não admite qualquer possibilidade de punição aos agentes que praticaram crimes comuns durante o período ditatorial.

$\mathrm{Na}$ verdade, embora tenha sido mais ampla do que a lei 6.683/79, também conhecida como lei de anistia, a finalidade principal da lei 10.559/03, conforme demonstra André Ramos Tavares e Walber de Moura Agra (In KISHI; SOARES. 2009, p.86) foi de "reconhecer e conceder indenização aos mortos e desaparecidos pelo regime militar, abrangendo todos que sofreram algum tipo de lesão por motivação política."

Apesar da lei 10.559/03 ter sido um avanço, devido ao amadurecimento das discussões acerca do período da ditadura militar, ainda se trata de uma legislação bastante limitada, uma vez que, conquanto a tarefa da reparação econômica nos termos da referida legislação seja aparentemente simples, tendo-se

${ }^{107}$ Nas explicações de Kai Ambos, Marcos Zilli, Maria Thereza Rocha de Assis Moura e Fabíola Girão Monteconrado (2010, p. 162-163): "Instalada pelo Ministério da Justiça no dia 28 de agosto de 2001, a Comissão foi criada pela Medida Provisória $\mathrm{n}^{\circ}$ 2.151, tendo por objeto o exame e o julgamento, em caráter administrativo, dos pedidos de indenização formulados por aqueles que foram impedidos de exercer atividades econômicas, em razão de perseguição política, durante o período de 18 de setembro de 1946 a 5 de outubro de 1998. É composta por quinze conselheiros que analisam o requerimento formulado diretamente pelo interessado ou por seus dependentes. A reparação econômica, prevista na Lei 10.559/02, deve ser concedida mediante portaria do Ministro da Justiça após parecer favorável da Comissão. A indenização poderá ser paga em prestação única, correspondente a 30 salários mínimos, por ano de perseguição política, desde que respeitado o limite de R 100 mil, ou em prestações mensais, permanentes e continuadas, correspondente à remuneração relativa ao posto, cargo, graduação ou emprego que o anistiado ocuparia, observado o limite do teto da remuneração do servidor público federal". 
em vista que não é necessária a constituição de advogado, tampouco a provocação da tutela jurisdicional, já que se trata de decisão com base na discricionariedade administrativa, a reparação somente se dá em "decorrência do impedimento do exercício de atividades econômicas, para o dano moral o único caminho possível permanece sendo a justiça comum.” (MEZAROBBA, 2006, pp. 137-138).

Nesse contexto, observa-se que as respostas legislativas ainda não se mostravam suficientes no sentido de expor as violações dos direitos civis durante o período militar. De qualquer forma observa-se que o Brasil adotou uma postura que acabou por perdurar no tempo, a necessidade de uma resposta institucional com o fito de buscar aquilo que verdadeiramente corresponde à realidade histórico-institucional do país.

Desta forma, o importante passo institucional de investigação do próprio passado representa irrefutável avanço até mesmo para a definição de valores os quais deverão ser socialmente considerados ${ }^{108}$.

Recentemente, entrou em vigor também, a lei 12.528 de 2011, que criou a Comissão Nacional da Verdade e que tem como finalidade, nos termos do seu art. $1^{\mathrm{o}}$ "examinar e esclarecer as graves violações de direitos humanos praticadas no período fixado no art. 80 do Ato das Disposições Constitucionais Transitórias, a fim de efetivar o direito à memória e à verdade histórica e promover a reconciliação nacional".

Da mesma forma que as legislações anteriores, a Comissão da Verdade criada pela lei 12.558 de 2011, por não estar investida de poder jurisdicional, não poderá também determinar qualquer tipo de punição aos agentes que praticaram ilícitos civis e crimes comuns em favor do regime militar.

Considerando o evoluir histórico, é de se ponderar que, com a criação da Comissão da Verdade no Brasil, revela-se certo atraso se comparado a realidade histórica observada noutros países da América Latina.

No entanto, como meio de fortalecimento das instituições, certamente a Comissão da Verdade, criada pela lei 12.558 de 2011, representa importante evolução legislativa e institucional na busca da identidade histórica, até mesmo pelo fato de que sua aprovação contou com os apoios de todos os ex-chefes de Estado do país, que ainda se encontram vivos ${ }^{109}$.

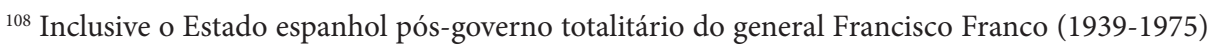
decidiu seguir adiante depois da ditadura franquista mediante o pacto de não mexer no passado. Em 2007, no entanto, a Lei da Memória Histórica para mudar nomes de ruas e locais públicos que homenageavam figuras-chave do regime provocou polêmica no país. Na época, até mesmo quem se opunha ao regime argumentou que a lei reavivava sentimentos de rivalidade e ia na direção contrária do pacto que permitiu o processo democrático no país pós-Franco. Disponível em http://ultimosegundo.ig.com.br/mundo/2012-05-16/comissao-da-verdade-chega-com-atraso-ao-brasil-em-relacao-a-outr.html. Acesso em 26.07.2012.

${ }^{109}$ Ex-presidentes da República elogiaram nesta quarta-feira (5) a criação da Comissão da Ver-
} 


\section{A responsabilidade civil do Estado em razão de danos reflexos OU RICOCHETES SOFRIDOS POR PARENTES E PESSOAS PRÓXIMAS ÀS VÍTIMAS DO REGIME MILITAR}

Conforme já mencionado a lei $10.559 / 03$, não tem o condão de compensar em razão de danos morais, aqueles que tiveram seus direitos violados pela ditadura, devendo as vítimas recorrer à tutela jurisdicional para serem reparadas em decorrência dos atos ilícitos praticados pelo Estado, naquele período.

Durante o período do regime militar, diversas pessoas foram injustamente atacadas, o que provocou inúmeras violações a diretos fundamentais, mesmo aqueles que somente foram reconhecidos pelo Estado brasileiro em momento posterior. Neste sentido a configuração dos danos às vítimas do período ditatorial está devidamente demonstrada na medida em que cumpre todos os requisitos necessários à possibilidade de responsabilização civil, quais sejam: a violação de um interesse jurídico tutelado e a certeza e subsistência do dano.

No entanto, apesar das legislações que surgiram em razão do amadurecimento sobre o debate do período transicional no Brasil, uma questão que se mostra pertinente é sobre a responsabilidade do Estado, em razão de danos, não somente em relação às vitimas, mas também, referente aos chamados danos reflexos ou ricochetes sofridos pelas pessoas próximas aos perseguidos pelo regime militar.

Diante dessa questão, surge um questionamento: haveria possibilidade de pessoas próximas as vitimas do regime militar, que perdurou entre $1964 \mathrm{e}$ 1985, serem reparadas em razão de danos reflexos ou ricochetes?

Para responder melhor o problema, é necessário antes definir o que se

dade, que investigará violações aos direitos humanos cometidos apurar as violações aos direitos humanos cometidos entre 1946 e 1988, período que inclui a ditadura militar. Em um gesto político de reconciliação com o passado, a presidente Dilma Rousseff desceu a rampa do Palácio do Planalto ao lado dos ex-presidentes Luiz Inácio Lula da Silva, Fernando Henrique Cardoso e José Sarney. "Foi um passo estupendo que a sociedade deu na conquista da democracia. É importante lembrar que foi a única comissão da verdade no mundo surgida de baixo para cima. Foi uma coisa surgida de povo para povo", afirmou o ex-presidente Luiz Inácio Lula da Silva. Fernando Henrique Cardoso destacou que a Comissão da Verdade não é uma questão política ou de governo. "Ela [Dilma] tratou essa questão como deve. É uma questão de Estado. Ela fez bem e reconheceu. Não é uma questão política, é uma questão de cidadania, de democracia. Com isso, ela motiva a comissão a agir pensando no Brasil." O ex-presidente Fernando Collor afirmou que ficou "emocionado" com o discurso da presidente Dilma na cerimônia de instalação da comissão. "É uma importância transcendental porque o Brasil se encontra consigo próprio no momento em que dá oportunidade para a verdade vir à tona. "Disponível em: http://g1.globo.com/politica/ noticia/2012/05/lula-ve-passo-estupendo-e-fhc-diz-que-dilma-fez-bem-ao-criar-comissao.html. Acessado em : 26 .07.2012. 
trata danos reflexos ou ricochetes, uma vez que a partir da compreensão de tal instituto jurídico é que será possível se chegar a uma resposta sobre o tema.

$\mathrm{Na}$ definição de Pablo Stolze e Rodolfo Pamplona Filho (2012, p. 91) o dano reflexo ou ricochete, apesar das dificuldades em conceituá-1o ${ }^{110}$, ainda mais em razão de danos morais devido à ausência de previsão expressa, "consiste no prejuízo que atinge reflexamente pessoa próxima, ligada à vítima direta da atuação ilícita”.

Contudo, conforme continua a expor Stolze e Pamplona Filho (2012, p. 93) não se deve confundir os chamados danos reflexos ou ricochetes com os denominados danos indiretos, visto que estes se referem "ao interesse juridicamente tutelado que tenha sido violado", como por exemplo, no caso do dano moral provocar posteriormente danos materiais à vítima ${ }^{111}$.

Nota-se, que a jurisprudência do Superior Tribunal de Justiça vem reconhecendo que os danos reflexos ou ricochetes, que somente são previstos pela lei para os danos materiais ou patrimoniais ${ }^{112}$, tem sua aplicação extensiva aos danos morais ou extrapatrimoniais ${ }^{113}$.

\footnotetext{
${ }^{110} \mathrm{Na}$ definição de Caio Mário da Silva Pereira (2000, p. 44) "Se o problema é complexo na sua apresentação, mais ainda o será na sua solução. $\mathrm{Na}$ falta de um princípio que o defina francamente, o que se deve adotar como solução é a certeza do dano. Se pela morte ou incapacidade da vítima, as pessoas, que dela se beneficiavam ficaram privadas de socorro, o dano é certo, e cabe ação contra o causador. Vitimando a pessoa que prestava alimentos a outras pessoas, privou-as do socorro e causou-lhes prejuízo certo. É o caso, por exemplo, da ex-esposa da vítima que, juridicamente, recebia dela uma pensão. Embora não seja diretamente atingida, tem ação de reparação por dano reflexo ou em ricochete, porque existe a certeza do prejuízo e, portanto, está positivado o requisito do dano como elementar da responsabilidade civil".

${ }^{111}$ No esclarecimento de Karl Larenz (1959, p. 194): "el daño indirecto comprende aquellos menoscabos que sobrevienen más tarde o que, como lá pérdida de capacidad para el trabajo, actúan permanentemente, o que, como las adquisiciones no efectuadas a causa de la infracción, no se manifestan em el mismo objeto que sufrió el daño, sino únicamente en el patrimonio de perjudicado."

${ }^{112}$ De acordo com Sérgio Cavalieri Filho (2010, p. 91), o Código Civil Português prevê que no caso de morte da vítima, haverá "o direito a indenização por danos não patrimoniais cabe, em conjunto, ao cônjuge e aos descendentes da vítima, na falta destes, aos pais ou outros ascendentes, e por último aos irmãos ou sobrinhos que o representam." Todavia, conforme continuar a expor o ilustre autor, "nosso Código Civil, lamentavelmente, nada dispôs a respeito. A regra do seu art. 948,II, entretanto, embora pertinente ao dano material, pode ser aplicada analogicamente para limitar a indenização pelo dano moral, àqueles que estavam em estreita relação com a vítima, como o cônjuge, companheira, filhos, pais e irmãos menores que viviam sob o mesmo teto."

${ }^{113}$ Direito civil. Responsabilidade civil. Compensação por danos morais. Legitimidade ativa. Pais da vítima direta. Reconhecimento. Dano moral por ricochete. Dedução. Seguro DPVAT. Indenização judicial. Súmula 246/STJ. Impossibilidade. Violação de súmula. Descabimento. Denunciação à lide. Impossibilidade. Incidência da súmula 7/STJ e 283/STF. 1. A interposição de recurso especial não é cabível quando ocorre violação de súmula, de dispositivo constitucional ou de qualquer ato normativo que não se enquadre no conceito de lei federal, conforme disposto no art. 105, III, "a" da CF/88. 2. Reconhece-se a legitimidade ativa dos pais de vítima direta para, conjuntamente
} 
Assumindo-se favorável a posição da existência de danos reflexos, inclusive em relação aos danos morais, cabe observar que em relação às vítimas do regime militar, muitas delas, tiveram pessoas próximas atingidas, ainda que indiretamente, pelos atos criminosos por parte de um Estado autoritário, que perdurou por cerca de vinte anos no Brasil.

Os parentes ou pessoas próximas às vítimas tiveram que conviver durante anos com a dor da perda ou sofrimento daqueles que foram injustamente atacados pelo Estado, por terem, corajosamente, se posicionados de forma contrária a um regime imposto de maneira ilegítima. Muitos, inclusive crianças e adolescentes à época dos fatos, tiveram que se exilar do país, haja vista que, embora não tenham atuados diretamente contra a ditadura militar passaram a serem perseguidos também, simplesmente, por serem pessoas próximas àqueles que se contrapuseram ao regime ${ }^{114}$.

A legitimidade de parentes ou pessoas próximas às vítimas da ditadura militar, de propor a ação de responsabilidade civil em razão de danos reflexos ou ricochetes tem sua origem em sistemas jurídicos de outros países, sobretudo os Estados europeus, que reconhecem essa possibilidade, visto que a origem do instituto se deu no direito francês ${ }^{115}$.

com essa, pleitear a compensação por dano moral por ricochete, porquanto experimentaram, comprovadamente, os efeitos lesivos de forma indireta ou reflexa. Precedentes.3. Recurso especial não provido. (STJ. REsp 1208949 / MG. Relatora: Ministra: Nancy Andrighi. T3 - Terceira Turma. Data do Julgamento: 07/12/2010. Data da Publicação: 15/12/2010).

${ }^{114} \mathrm{Na}$ narrativa de Tatiana Moreira Campos Paiva (2009a, p. 136) "ao concentrarmos nas crianças e adolescentes filhos de militantes o foco de estudo, lidamos com uma situação bem diversa e bastante peculiar. A experiência de exílio neste caso foi consequência de laços familiares e não de intervenções políticas. O exílio de seus pais esteve diretamente relacionado com suas empreitadas contra o regime militar, sendo possível identificar como objetivo principal do exílio a "tentativa de exclusão de grupos ou indivíduos que manifestavam opiniões contrárias ao status quo, e lutaram para alterá-lo" (Rollemberg, 1999, p.25). Já para os filhos de militantes, a realidade do exílio aconteceu em decorrência das opções políticas de seus pais, e não de suas próprias escolhas. Há uma determinante diferença nesses dois exemplos percebida no caráter ativo de um ano e no aspecto passivo do outro. É a partir dessa perspectiva que podemos pensar na ideia de herança e reconhecer essas crianças como herdeiros do exílio. A falta de participação política no período em questão aponta para particularidades na experiência de meninos e meninas brasileiros, o que torna esse um caso diferente em sua essência. Através do exílio, as crianças e adolescentes deixaram um pouco de lado os papéis de coadjuvantes nesta história e construíram uma relação própria com o período da Ditadura Militar.

${ }^{115}$ Arnaldo Rizzardo (2007, p. 915) "analisando os sistemas jurídicos estrangeiros, observa que no direito francês a reparação abrange um interesse imediato ou mediato. No direito italiano, o interesse tutelado é apenas imediato. No ordenamento inglês, o autor de um direito só fica constrangido a indenizar o cônjuge, os descendentes e os ascendentes da pessoa morta. Excluem-se os demais parentes. O direito alemão, mantendo as diretrizes básicas do sistema italiano e inglês, autoriza o exercício da ação em favor dos parentes acima mencionados e dos terceiros para os quais o falecido se encontrava eventualmente obrigado à manutenção". 
Estando reconhecido pelo direito brasileiro, a possibilidade de reparação em decorrência de danos reflexos ou ricochetes, fica também preenchida todas as condições da ação ${ }^{116}$ necessárias a responsabilização do Estado, proveniente das práticas arbitrárias durante o regime militar.

Registre-se que o interesse de agir está na utilidade da prestação jurisdicional (AMORIM. 2009, p.78), que tenha como intuito, compensar, de forma necessária e adequada, àqueles que sofreram danos, por ter um parente ou uma pessoa próxima lesada pela prática de um Estado arbitrário.

Já a possibilidade jurídica do pedido se mostra também devidamente configurada, na medida em que a pretensão jurídica está resguardada pela legislação pátria e pela própria Constituição Federal de 1988, em seu art. $5^{\circ}$, V.

Por fim, não há o que se discutir sobre a legitimidade das partes envolvidas, seja no polo passivo, pois que os agentes da opressão agiram em nome do Estado, que por sua vez possui responsabilidade objetiva, em relação aos seus atos comissivos, seja no polo ativo, em que a legitimação ordinária ${ }^{117}$, é imputada aos parentes e às pessoas próximas às vitimas da ditadura militar, visto que sofreram danos extremamente graves ao presenciarem e suportarem as consequências das perseguições ocorridas em relação aos seus entes queridos.

Neste sentido, havendoclara certeza do dano, torna-se evidente a existência de danos materiais assim como de danos morais em relação aos familiares e pessoas próximas das vítimas do período ditatorial. Os danos materiais decorrem dos prejuízos patrimoniais sofridos pelos parentes das vítimas, como por exemplo, o fato de que muitos tiveram sua subsistência prejudicada, na medida em que a pessoa que era fonte de sustento de sua família foi arbitrariamente presa ou até mesmo vítima de homicídio. Já os danos morais, derivam do fato de ter ocorrido graves violações a direitos de personalidade, tanto daqueles que se contrapuseram ao regime, como também das pessoas que estavam próximas a estes.

Vale destacar que no caso de morte da vítima em decorrência das condutas praticadas pelos agentes estatais durante o regime militar o prejuízo aos familiares e pessoas próximas, deverão ser presumidos, haja vista que o Direito não pode se limitar a regramentos técnicos, de modo a impedir a aplicação básica da justiça ${ }^{118}$.

\footnotetext{
116 "Embora abstrato e ainda até certo ponto genérico, o direito de ação pode ser submetido a condições por parte do legislador ordinário. São as denominadas condições da ação (possibilidade jurídica, interesse de agir, legitimação as causam), ou seja, condições para que legitimamente se possa exigir, na espécie o provimento jurisdicional" (CINTRA, GRINOVER, DINAMARCO, 2002, p. 258).

${ }^{117}$ Daniel Amorim (2009, p.81) explica que em relação às condições da ação a legitimidade pode ser ordinária ou extraordinária. Será ordinária quando "o sujeito em nome próprio" defender "interesse próprio". Já a legitimação extraordinária será excepcionalmente admitida quando "alguém em nome próprio litigue em defesa do interesse de terceiro".

${ }^{118}$ José Jeová Santos (1999, p.236) observa que "em se tratando de dano patrimonial ou moral, em
} 
Ressalta-se, que apesar da legalidade instituída, que dava suporte às práticas estatais abusivas, no âmbito internacional, já vigoravam as normas de direitos humanos, sendo que em decorrência do sistema do jus cogens, que se contrapõe a ideia de bilateralidade de tratados em favor do costume internacional, deve-se dar validade a aplicação de normas relativas à proteção da dignidade da pessoa humana, durante o período da ditadura militar, diante as graves violações praticadas.

Não obstante o Supremo Tribunal Federal, no julgamento da ADPF 153, tenha desconsiderado a necessidade de uma interpretação dialógica com as Cortes Internacionais, indo além da ideia convencionalidade, no que tange a aplicação dos tratados internacionais, os direitos fundamentais, que são devidamente reconhecidos pela Constituição Federal de 1988, foram abruptamente transgredidos.

Por derradeiro, sendo as normas de jus cogens infringidas, como ocorreu no Estado brasileiro, devido a práticas reiteradas de violações a direitos humanos, apesar de os agentes terem agido em nome de uma legalidade interna, no âmbito internacional violaram as regras estabelecidas, o que por si só gera o direito a reparação ${ }^{119}$.

Sobretudo em relação aos danos morais que, conforme já mencionado, não possuem previsões específicas quanto ao dano ricochete e a forma de reparação disciplinada pela lei $10.559 / 03$, as práticas estatais do regime, pelo fato de terem violadas regras internacionais e, consequentemente provocados traumas de ordem psicológica às pessoas próximas às vítimas, obriga o Estado a indenizar ou compensar em decorrência dos prejuízos causados.

É muito importante esclarecer que o prejuízo indenizável ultrapassa a esfera patrimonial, podendo recair sobre a própria condição do homem, sem que haja uma valoração pecuniária pré-estabelecida.

decorrência da perda da vida, o prejuízo, nos dois âmbitos é presumido. Não se indaga como e em que grau a perda da vida afetou a outros, nos aspecto patrimonial em que isso é mais sentido. Afinal, é a vida o bem supremo e a sua proteção ou quando esse bem é violado, não pode ficar preso a dogmas do Direito".

${ }^{119}$ Como bem explica Roberto Lima Santos (2010, p.239-240) as" consequências da ocorrência de um fato ilícito qualificado (ou crime internacional) estão previstas no art. 41 da CDI de 2005. Elas são de duas categorias: em relação à vítima e outra em relação ao estatuto jurídico dos demais Estados da comunidade internacional. No tocante à vítima, a reparação deve ser total, devendo ser efetuada a restituição na íntegra ou outra forma de reparação, sem que possa o Estado infrator opor qualquer tipo de impedimento. Em relação ao estatuto jurídico dos demais Estados da comunidade internacional, elas geram obrigações para toda a comunidade internacional, a saber: não reconhecer como legal a situação gerada pelo infrator, não auxiliar o Estado infrator a manter a dita situação ilegal, auxiliar outros Estados para fazer cumpriras duas obrigações acima expostas; cooperar entre si para aplicar medidas destinadas a eliminar as consequências do fato ilícito qualificado." 
Desse modo expõe Luiz Edson Fachin (apud STOLZE, 2012, p. 83):

A pessoa, e não o patrimônio, é o centro do sistema jurídico, de modo que se possibilite a mais ampla tutela da pessoa, em uma perspectiva solidarista que se afasta do individualismo que condena o homem a abstração. Nesta esteira, não há, pois, direito subjetivo arbitrário, mas sempre limitado pela dimensão coexistencial do ser humano. $\mathrm{O}$ patrimônio, conforme se apreende do exposto por Sessarego, não só deixa de ser o centro do Direito, mas também a propriedade sobre os bens é funcionalizada ao homem, em sua dimensão coexistencial.

De maneira especial o dano extrapatrimonial, ao "atingir valores eminentemente espirituais ou morais" (RIZZARDO, 2007, p. 246), deverá ser compensado de maneira que o caráter pedagógico e reparatório da responsabilidade civil seja alcançado, não podendo o Estado se eximir de realizar o pagamento, que será fixado, de modo a impedir que a prática antijurídica se repita.

As atuações dos magistrados e dos tribunais, por sua vez, deverão estar vinculadas aos direitos fundamentais, de maneira que questões meramente formais, a ponto de impedir a reparação, não deverão ser consideradas, haja vista que o Estado brasileiro durante a ditadura militar estava diante de um processo de anormalidade institucional.

\section{A inexistênCIA de PRESCRIÇÃo da REPARAÇÃo CIVIL POR DANOS RICOCHETES OU REFLEXOS DOS PARENTES E PESSOAS PRÓXIMAS DAS VÍTIMAS DA DITADURA MILITAR}

Nos termos do art. 206, $\S 3^{\circ}$, I do Código Civil, prescreve em três anos a pretensão da reparação civil. No que tange a responsabilidade civil do Estado este prazo passa para cinco anos, em decorrência do art. $1^{\circ}$ do decreto 20.910/32.

Fazendo-se uma interpretação puramente normativa poderia se concluir que a reparação civil em relação às vítimas da ditadura militar e aos parentes ou pessoas próximas a elas, não seria cabível, uma vez que, em razão do decurso do tempo, teria ocorrido a perda da pretensão da ação ${ }^{120}$.

Todavia, caso essa posição viesse prevalecer, haveria uma irrazoabilidade na decisão que julgasse o mérito da demanda, uma vez que

\footnotetext{
${ }^{120}$ Na definição de Cássio Scarpinella Bueno (2011, p.387), diferentemente da decadência em que há a perda do próprio direito, a prescrição se trata da "perda de possibilidade de exigir o direito em face de outrem".
} 
não se pode considerar preceitos normativos que são aplicados em períodos de normalidade democrática, em situação em que houve graves violações de direitos humanos.

Nota-se que no caso da prescrição e decadência, a opção do legislador deverá ser recusada, na hipótese de haver "alguma agressão ao modelo constitucional do direito processual civil." (BUENO, 2011, p.387). Ainda mais pelo fato de que, conforme muito bem assinalou Paulo Bonavides (2001, p.233), "nenhum princípio é mais valioso para compendiar a unidade material da Constituição do que o princípio da dignidade humana".

Conforme já mencionado, o Brasil, mesmo que durante o período da ditadura militar, não tenha aderido como signatário na maioria dos tratados de direitos humanos ${ }^{121}$, estava submetido ao costume internacional, ou seja, não poderia ir contra ao estabelecido pelas chamadas normas de jus cogens.

Além disso, deve-se constatar que se a Constituição Federal de 1988 é "um documento de grande importância para o constitucionalismo em geral", conforme observou José Afonso da Silva (p.89, 2003), tal relevância dada a Carta Magna, somente possui sentido se houver eficácia dos direitos e garantias fundamentais ali previstos, por meio da aplicabilidade prática.

Em face de tal cenário, não se pode considerar a prescrição, uma vez que "o constitucionalismo - compreendido paradigmaticamente - coloca freios à discricionariedade própria do positivismo-normativista" (STRECK apud NUNES, 2009 p. 193).

Logo, não se pode submeter os direitos que foram gravemente violados pelo regime militar a meras questões técnicas interpretadas por exegetas que analisam a norma sem observar o contexto em que se insere e sua harmonia com o ordenamento jurídico vigente ${ }^{122}$.

Ressalta-se que a própria ideia de Estado de Direito, exige uma atuação no sentido de que não se permita a inexistência de resposta diante graves violações praticadas. Neste sentido expõe Norberto Bobbio (2001, p.170):

${ }^{121}$ Conforme expõe Flávia Piovesan (2007, p.272), desde o "processo de democratização do País e em particular a partir da Constituição Federal de 1988, o Brasil tem adotado importantes medidas em prol da incorporação de instrumentos internacionais voltados a proteção dos direitos humanos. O marco inicial do processo de incorporação do Direito Internacional dos Direitos Humanos pelo Direito brasileiro foi a ratificação, em $1^{\circ}$ de fevereiro de 1984, da Convenção sobre a Eliminação de todas as formas de discriminação contra a Mulher. A partir dessa ratificação, inúmeros outros relevantes instrumentos internacionais de proteção dos direitos humanos foram também incorporados pelo Direito brasileiro, sob a égide da Constituição Federal de 1988, que, como já visto, situa-se como marco jurídico da transição democrática e da institucionalização dos direitos humanos no País.

122 Nas explicações de Norberto Bobbio (2001, p.167) a "sanção organizada como elemento constitutivo de direito" não se refere as "normas singulares", mas sim "ao ordenamento normativo tomado em seu conjunto". 
O "Estado de direito" avançou e continua a avançar na medida em que se substituem os poderes arbitrários pelos juridicamente controlados, os órgãos responsáveis pelos órgãos juridicamente responsáveis, enfim, na medida em que o ordenamento jurídico organiza a resposta às violações que provém não só dos cidadãos privados, mas também dos funcionários públicos.

Cumpre ressaltar que, os tribunais pátrios vem decidindo no sentido de que não se deve considerar o prazo prescricional, no que tange a responsabilização do Estado pelas práticas violadoras de direitos humanos, durante o regime militar. É o entendimento inclusive demonstrado pelo Superior Tribunal de Justiça, no julgamento do REsp 1104731 / RS, conforme pode se constatar:

Administrativo. Responsabilidade civil do Estado. Indenização por danos morais. Regime militar. Tortura. Imprescritibilidade. Inaplicabilidade do art. $1^{\text {o }}$ do decreto 20.910/1932. Quantum indenizatório. Revisão. Impossibilidadade. 1. As ações indenizatórias por danos morais decorrentes de atos de tortura ocorridos durante o Regime Militar de exceção são imprescritíveis. Inaplicabilidade do prazo prescricional do art. $1^{\mathrm{o}}$ do Decreto 20.910/1932. Precedentes do STJ. 2. O Brasil é signatário do Pacto Internacional sobre os Direitos Civis e Políticos das Nações Unidas incorporado ao ordenamento jurídico pelo Decreto-Legislativo 226/1991, promulgado pelo Decreto 592/1992 -, que traz a garantia de que ninguém será submetido a tortura, nem a pena ou a tratamentos cruéis, desumanos ou degradantes, bem como prevê a proteção judicial para os casos de violação de direitos humanos 3. A Constituição da República não estipulou lapso prescricional à faculdade de agir, correspondente ao direito inalienável à dignidade. 4. Hipótese em que o Tribunal de origem, ao concluir, diante da documentação colacionada aos autos, que o autor foi realmente preso e torturado, tendo sofrido danos psicológicos permanentes, fixou indenização por danos morais em $\mathrm{R} \$ 300.000,00$ (trezentos mil reais). 5. A jurisprudência do STJ é pacífica no sentido de que somente em casos excepcionais é possível rever o valor da indenização, quando exorbitante ou insignificante a importância arbitrada, em flagrante violação dos Princípios da Razoabilidade e da Proporcionalidade, o que, in casu, não se configura. 6. Recurso Especial não provido.

Da mesma forma foi o entendimento proferido em julgamento sobre caso semelhante no Tribunal Regional Federal da $4^{\mathrm{a}}$ Região, na Apelação Cível: 2002.70.00.013602-4: 
Administrativo. Dano moral. Perseguição política. Regime militar. Leis 9.140/95 e 10.536/02. Prescrição. Prova dos danos causados. Indenização. Fixação. Circunstâncias de fato. Motivação. Razoabilidade. 1. A prescrição serve para situações de normalidade; não, contudo, para fatos excepcionais em sua gravidade, como os ocorridos durante $\mathrm{o}$ regime ditatorial militar, e em relação aos quais as vítimas, por muito tempo, estiveram impossibilitadas de se insurgir. 2. A promulgação das Leis 9.140/95 e 10.536/02 importou em reconhecimento do Estado quanto a sua responsabilidade pelos abusos cometidos por seus agentes durante aquele período, reabrindo os prazos justamente para permitir que as vítimas pleiteassem indenização do Estado. 3. Reconhecido o direito da parte autora à indenização em face da perseguição política por conta da sua condição de filiado a partido de orientação contrária ao regime militar. Indenização devida, inclusive, em razão da prova da ocorrência de agressões físicas e morais. 4. O arbitramento da indenização advinda de danos morais deve levar em conta o bom senso e a razoabilidade, atendendo às peculiaridades do caso, não podendo ser fixado quantum que torne irrisória a condenação, tampouco valor vultoso que traduza enriquecimento ilícito. 5. Hipótese em que, sopesadas as circunstâncias do caso concreto, o contexto político e social em que ocorreram os fatos, e as razões que motivaram os abusos por parte do regime, mantém-se a indenização arbitrada em R \$ 50.000,00 (cinqüenta mil reais).

Salienta-se que, na medida em que o julgamento por dano moral em razão de danos reflexos ou ricochetes em relação a pessoas próximas ou parentes das vítimas da ditadura militar envolve a análise de transgressão de direitos fundamentais, exige-se, em decorrência da vinculação dos órgãos jurisdicionais a tais direitos, que sejam observados os princípios formatadores do Estado Democrático, de modo em que o processo judicial seja modulado para atender aos ditames constitucionais.

É o que demonstra Ingo Wolfgang Sarlet (2005, p.369):

[...] é de destacar-se o dever de os tribunais interpretarem e aplicarem as leis em conformidade com os direitos fundamentais, assim como o dever de colmatação de eventuais lacunas à luz das normas de direitos fundamentais, o que alcança, inclusive, a Jurisdição cível, esfera na qual - ainda que numa dimensão diferenciada- também se impõe uma análise de influência exercida pelos direitos fundamentais sobre as normas de direito privado. Neste contexto, constata-se que os direitos fundamentais constituem, ao mesmo tempo, parâmetros 
materiais e limites para o desenvolvimento judicial do Direito. Por outro lado, a condição peculiar do Poder Judiciário, na medida em que, sendo simultaneamente vinculado à Constituição (e aos direitos fundamentais) e às leis, possui o poder-dever de não aplicar as normas infraconstitucionais, revela que eventual conflito entre os princípios da legalidade e da constitucionalidade (isto é entre lei e constituição) acaba por resolver-se em favor do último.

Observa-se também que a própria noção de direitos fundamentais, que se caracterizam como uma "categoria jurídica, constitucionalmente erigida e vocacionada à proteção da dignidade humana em todas as dimensões" (ARAUJO. NUNES JÚNIOR. 2008, p. 110), quando violados, tem se a tese de que tais direitos são imprescritíveis ${ }^{123}$, pois que, são à base do ordenamento jurídico presente no Estado Democrático.

Notadamente, como muito bem leciona Flávia Piovesan (2007, p.288) o "binômio democracia e direitos humanos se faz premente na experiência brasileira, tendo em vista que o projeto democrático está absolutamente condicionado à garantia dos direitos humanos".

Diante disso, tendo havido graves violações a direitos fundamentais pelo regime militar, torna-se imprescindível o reconhecimento da imprescritibilidade, tanto na esfera penal como também na esfera civil, uma vez que, somente dessa forma, será possível responsabilizar o Estado, diante as práticas criminosas adotadas durante o período ditatorial.

\section{Conclusão}

Por todos os elementos trazidos nesse estudo, que não pretendeu esgotar o tema da reparação civil por danos reflexos ou ricochetes, observase a necessidade de se revisitar os critérios, bem como as condicionantes e motivadores históricos, primeiramente da Lei 6.683/79.

Nesse sentido, verifica-se que não se pode mais colocar no mesmo patamar os agentes opressores com aqueles que foram perseguidos por todo o aparato do Estado que, por sua vez, tiveram suas histórias e de seus familiares estigmatizadas pelo agir estatal, perseguidor e opressor.

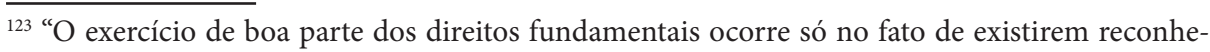
cidos na ordem jurídica. Em relação a eles não se verificam requisitos que importem em sua prescrição. Vale dizer, nunca deixam de ser exigíveis. Pois prescrição é um instituto jurídico que somente atinge, coarctando, a exigibilidade dos direitos de caráter patrimonial, não a exigibilidade de direitos personalíssimos, ainda que não individualistas, como é o caso. Se são sempre exercíveis e exercidos, não há intercorrência temporal de não exercício que fundamente a perda da exigibilidade pela prescrição." (SILVA. 2003, p.181). 
Desta forma, diante de um Estado de não direito instituído em 1964 e que perdurou até 1985, necessária se faz uma Justiça de Transição efetiva capaz de corrigir todas as assimetrias, principalmente aquelas que evidenciam que o Estado ali imposto foi outorgado e não democrático.

Leia-se o Direito como realidade conformadora, legitimada capaz de garantir a paz e a ordem social, e não sendo esse o entendimento, o agir estatal destoante dos princípios do ordenamento jurídico devem ser passíveis de responsabilização.

Ademais, no sentido de se verificar a responsabilização do Estado pelos danos reflexos ou ricochetes, constata-se que todos os elementos ensejadores para a reparação civil em decorrência do dano, encontram-se devidamente configurados.

Portanto, como forma de correção história da deflagração estatal contra os direitos individuais, bem como aos direitos humanos outrora reconhecidos, deve-se evoluir no sentido de não apenas buscar a realidade histórica, mas, também, em reconhecer a possibilidade de reparação civil aos parentes e pessoas próximas das vítimas da ditadura militar. 


\section{REFERÊNCIAS}

AFONSO, Beatriz. KRSTICEVIC. Viviana. A importância de se fazer justiça: Reflexões sobre os desafios para o cumprimento da obrigação de investigar e punir os responsáveis em observância a sentença da Corte Interamericana no caso da Guerrilha do Araguaia. In: GOMES, Luiz Flávio; MAZZUOLI, Valério de Oliveira (Org.). Crimes da Ditadura Militar: Uma análise à luz da jurisprudência atual da Corte Interamericana de Direitos Humanos. São Paulo: Revista dos Tribunais, 2011.

AGRA, Walber de Moura. TAVARES, André Ramos. Justiça Reparadora no Brasil. In: KISHI, Sandra Akemi Shimada; SOARES, Inês Virgínia Prado (Org.); Memória e Verdade: A Justiça de Transição no Estado Democrático Brasileiro. Belo Horizonte: Forum, 2009.

ARAUJO, Luiz Alberto David. NUNES JÚNIOR, Vidal Serrano. Curso de Direito Constitucional. 12. ed. São Paulo: Saraiva, 2008.

BOBBIO. Norberto. Teoria da Norma Jurídica. Trad. Fernando Pavan Baptista e Ariani Bueno Sudatti / apresentação: Alaor Caffé Alves. Bauru/SP: EDIPRO, 2001.

BONAVIDES. Paulo. Teoria constitucional da democracia participativa. São Paulo: Malheiros, 2001.

BUENO. Cássio Scarpinella. Direito processual civil - Procedimento comum: procedimento ordinário e sumário. 4. ed. São Paulo: Saraiva, 2011.

CANOTILHO, José Joaquim Gomes. Estado de direito. 1. ed. Lisboa: Gradiva Publicações/Fundação Mário Soares, 1999.

CARVAlHO FILHO. José dos Santos. Manual de Direito Administrativo. 11. ed. Rio de Janeiro: Lumen Juris, 2004.

CAVAliERI FILHO. Sérgio. Programa de Responsabilidade Civil. 9. ed. São Paulo: Atlas, 2010.

CINTRA. Antônio Carlos de Araújo. DINAMARCO. Cândido Rangel. GRINOVER. Ada Pellegrini. Teoria Geral do Processo. 18. ed. São Paulo: Malheiros, 2002. 
COMPARATO. Fábio Konder. Comentário ao art. 1. In: CASTRO, Reginaldo Oscar de (Coord.). Direitos Humanos: conquistas e desafios. Brasília: Letraviva, 1999.

DI PIETRO. Maria Sylvia Zanella. Direito Administrativo. 19. ed.. São Paulo: Atlas, 2006.

FERRAJOLI. Luigi. A soberania no mundo moderno. Trad. Carlo Coccioli, Márcio Lauria Filho. Revisão: Karina Janninni. São Paulo: Martins Fontes, 2002.

GAGLIANO, Pablo Stolze. PAMPLONA FILHO, Rodolfo. Novo Curso de Direito Civil: Responsabilidade Civil. 10. ed. São Paulo: Saraiva, 2012.

HERKENHOFF, João Baptista. Direito e Cidadania. São Paulo: Uniletras, 2004.

LARENZ, Karl. Derecho de Obligaciones. Trad. ao espanhol de Jaime Santos Briz. Madrid: Revista de Derecho Privado, 1959, tomo 2.

LYRA FILHO. Roberto. O que é Direito. 15. reimp. da 17. ed. São Paulo: Brasiliense, 2006.

MAIEROVITCH, Wálter. Supremos Momentos. Disponível em: http://www. cartacapital.com.br/politica/supremos-momentos/?autor=18. Acessado em: 13.07.2012.

MASCARO. Alysson Leandro. Crítica da Legalidade e do Direito Brasileiro. 2. ed. São Paulo: Quartier Latin, 2008.

MELLO. Celso Antônio Bandeira de. Curso de Direito Administrativo. 14. ed. São Paulo: Malheiros, 2002.

MEZAROBBA. Glenda. Um acerto de contas com o futuro: a anistia e suas consequências: um estudo do caso brasileiro. São Paulo: Humanitas, 2006.

MONTECONRADO, Fabíola Girão; MOURA, Maria Thereza Rocha de Assis; ZILLI, Marcos; A Justiça de Transição no Brasil: Um caminho ainda a percorrer. In: AMBOS, Kai; MONTECONRADO, Fabíola Girão; MOURA, Maria Thereza Rocha de Assis; ZILLI, Marcos. Anistia, Justiça e Impunidade: 
Reflexões sobre a Justiça de Transição no Brasil. Belo Horizonte: Forum, 2010.

NEVES. Daniel Amorim Assumpção. Manual de Direito Processual Civil. São Paulo: Método, 2009.

NUNES. Dierle José Coelho. Processo Jurisdicional Democrático: Uma análise crítica das reformas processuais. 1. ed. Curitiba: Juruá, 2009.

PAIVA. Tatiana Moreira Campos. Memórias de uma herança: a experiência de filhos de exilados brasileiros da ditadura militar. In: SANTOS, Cecília Macdowell; TELES. Edson; TELES; Janaína de Almeida (Org.). Desarquivando a ditadura: memória e Justiça no Brasil. vol. 1. São Paulo: Hucitec, 2009a.

PEREIRA. Caio Mário da Silva. Responsabilidade Civil. 9. ed. Rio de Janeiro: Forense, 2000.

PIOVESAN. Flávia. Direitos Humanos e o Direito Constitucional Internacional. 8. ed. São Paulo: Saraiva, 2007.

RIZZARDO. Arnaldo. Responsabilidade Civil. 3. ed. Rio de Janeiro: Forense, 2007.

SANTOS. José Jeová dos. Dano Moral Indenizável. 2. ed. São Paulo: LEJUS, 1999.

SANTOS. Roberto Lima. Crimes da ditadura militar: Responsabilidade Internacional do Estado Brasileiro por Violação aos Direitos Humanos. Porto Alegre: Núria Fabris, 2010.

SARLET. Ingo Wolfgang. A Eficácia dos Direitos Fundamentais. 5. ed. Porto Alegre: Livraria do Advogado, 2005.

SILVA. José Afonso da. Curso de Direito Constitucional Positivo. 22 ed. São Paulo: Malheiros, 2003.

STF. ADPF 153. Relator: Min. Eros Grau. Data do Julgamento: 29/04/2010. Data da Publicação: 06/08/2010. Disponível em: http://redir.stf.jus.br/paginadorpub/ paginador.jsp?docTP=AC\&docID=612960. Acessado em: 23.06.2012.

STJ. REsp 1104731 / RS. Relator: Ministro Herman Benjamin. T2 - Segunda Turma. Data do Julgamento: 05/03/2009. Data da Publicação: 05/11/2009. 
Disponívelem: http://www.stj.jus.br/SCON/jurisprudencia/doc.jsp?livre=PRESCR $\mathrm{I} \% \mathrm{C} 7 \% \mathrm{C} 3 \mathrm{O}+\mathrm{RESPONSABILIDADE}+\mathrm{CIVIL}+\mathrm{DO}+\mathrm{ESTADO}+\mathrm{DITADURA}+\mathrm{M}$ ILITAR $\& \& b=A C O R \& p=$ true $\& \mathrm{t}=\& \mathrm{l}=10 \& \mathrm{i}=3$. Acessado em: 23.06.2012.

. REsp 1208949 / MG. Relatora: Ministra: Nancy Andrighi. T3 - Terceira Turma. Data do Julgamento: 07/12/2010. Data da Publicação: 15/12/2010. Disponível em:http://www.stj.jus.br/SCON/jurisprudencia/toc.jsp?tipo_vi sualizacao $=$ RESUMO\&livre=\%28\%22NANCY+ANDRIGHI\%22\%29. min.\&processo $=1208949 \& b=A C O R$. Acessado em: 23.06.2012.

SWENSSON JÚNIOR, Lauro Joppert. Punição para os crimes da ditadura militar: contornos do debate. In: DIMOULIS, Dimitri. MARTINS, Antônio. SWENSSON JÚNIOR, Lauro Joppert. Justiça de Transição no Brasil: Direito, Responsabilização e Verdade. São Paulo: Saraiva, 2010.

TENTANDO APAGAR A HISTÓRIA DA DITADURA, POR VLADIMIR SAFLATE. Carta Capital. Disponível em: http://www.cartacapital.com.br/ politica/vladimir-safatle-tentando-apagar-a-historia-da-ditadura/. Acessado em: 10.07.2012.

TRF4. Apelação Cível: 2002.70.00.013602-4. Relator: Valdemar Capeletti. Data do Julgamento: 30/04/2008. Data da Publicação: 26.05.2008. Disponível em: http://jurisprudencia.trf4.jus.br/pesquisa/resultado_pesquisa.php. Acessado em: 23.06.2012.

TELLES. Antônio Queiroz. Introdução ao Direito Administrativo. São Paulo: Revista dos Tribunais, 1995.

WOLKMER. Antônio Carlos. Ideologia, Estado e Direito. 4. ed. São Paulo: Revista dos Tribunais, 2003.

\section{Periódicos}

http://g1.globo.com/politica/noticia/2012/05/lula-ve-passo-estupendo-e-fhcdiz-que-dilma-fez-bem-ao-criar-comissao.html. Acessado em: 26.07.2012. http://ultimosegundo.ig.com.br/mundo/2012-05-16/comissao-da-verdadechega-com-atraso-ao-brasil-em-relacao-a-outr.html. Acessado em 26.07.2012. 